\title{
PEMANFAATAN BOKHASI, IRIGASI PROBASA, HIDROPONIK PADA TANAMAN HORTIKULURA PADA LAHAN KERING
}

\author{
Arnold. Christian Tabun ${ }^{1)}$, C. L O. Leo Penu ${ }^{1)}$ A. Sinurat ${ }^{2)}$ V. D. Tome ${ }^{1)}$, dan T. Lapenangga ${ }^{1)}$ \\ ${ }^{1)}$ Politeknik Pertanian Negeri Kupang; \\ ${ }^{2)}$ Universitas Nusa Cendana \\ Email: arnold.tabun@gmail.com
}

\begin{abstract}
ABSTRAK
Keterbatasan pengetahuan kelompok tani dan sumber daya air sering menjadi kendala dalam budidaya tanaman hortikultura di lahan sempit dan kering. Untuk mengatasi permasalahan petani tersebut diperlukan sentuhan teknologi budidaya tanaman di lahan sempit dan lahan kering. Metode pengabdian adalah penyuluhan, demplot dan pendampingan. Kebun contoh tanaman hortikulutura di Kelompok Tani Tunas Baru menggunakan pupuk Bokhasi, mulsa plastik dan irigasi semprot bawah mulsa (Pro-Basa) dapat meningkatkan produksi tanaman hortikultura dan pendapatan petani. Untuk memanfaatkan pekarangan rumah dan lahan yang sempit, dapat menggunakan penanaman secara hidroponik dan polybag sebagai media tanam. Simpulan dari pengabdian adalah tersedianya kebun contoh tanaman semi organik di lahan kering, peningkatan pengetahuan dalam budidaya tanaman hortikultura di lahan kering menggunakan bokhasi, irigasi Pro-basa, aplikasi sistem hidroponik dan pemanfaatana pupuk oranik cair untuk budidaya sayuran di pekarangan sempit serta adanya peningkatan pendapatan petani dalam usaha tanaman hortikultura pada lahan kering
\end{abstract}

Keywords: Bokhasi, Irigasi Pro-Basa, Hidroponik, Pupuk Cair

\section{PENDAHULUAN}

Kelompok Tani Tunas Baru dan Kaum Bapak Jemaat GMIT Bait El di Kampung Baru-Penfui yang berada di dataran rendah dengan kondisi lahan yang kering dan curah hujan rendah berkisar 3-4 bulan/tahun. Kondisi lahan kering menyebabkan kurangnya pemanfaatan lahan dalam usaha pertanian karena terbatasnya air dan suhu yang sangat panas. Salah satu alternatif dalam pemanfaatan lahan kering dengan usaha pertanian adalah dengan memanfaatkan air tangki untuk penyiram. Selain itu juga banyak sampah-sampah organik yang belum dimanfaatkan sebagai pupuk organik. Upaya yang dilakukan pembuatan kebun hortikultura pada lahan kering skala rumah tangga dengan memanfaatkan sampah atau limbah organik yang ada disekitar masyarakat. Lokasi demplot merupakan halaman 
pekarangan rumah yang memiliki ternak peliharaan yang limbahnya belum optimal digunakan sebagai sumber pupuk organik. Bahkan cenderung limbah ternak tersebut dapat menjadi masalah pencemaran bagi lingkungan maupun masyarakat sekitar. Kegiatan pengabdian ini, bertujuan mengaplikasikan berbagai teknologi seperti sistem irigasi Pro-Basa yang telah berhasil dikembangkan dan juga model pemanfaatan media sederhana polybag dan hidroponik terhadap usaha masyarakat petani.

\section{METODE}

Metode yang digunakan dalam pelaksanaan pengabdian ini adalah Penyuluhan tentang pemanfaatan lahan kering dalam meningkatkan hasil tanaman hortikultura, Pembuatan demplot Bokhasi, Pelatihan hidroponik dan pupuk cair organic limbah rumah tangga

\section{HASIL DAN PEMBAHASAN}

Kegiatan utama pada tahap awal dalam kegiatan pengabdian ini adalah pembuatan demplot kebun hortikultura pada lahan kering skala rumah tangga dengan memanfaatkan sampah atau limbah organik yang ada disekitar masyarakat. Pembuatan demplot ini dilakukan dengan melibatkan petani dari Kelompok Tani Tunas Baru dan juga jemaat GMIT Bait El Kampung Baru Penfui. Lokasi demplot merupakan halaman pekarangan rumah yang memiliki ternak peliharaan yang limbahnya belum optimal digunakan sebagai sumber pupuk organik. Bahkan cenderung limbah ternak tersebut dapat menjadi masalah pencemaran bagi lingkungan maupun masyarakat sekitar. Selain limbah ternak, juga sampah organik yang dapat dimanfaatkan sebagai pupuk tetapi banyak sampah yang dibuang disekitar lingkungan yang dapat menyebabkan pencemaran lingkungan.

Pertanian organik adalah suatu sistem pertanian atau usahatani yang tidak mempergunakan bahan kimia, tetapi menggunakan bahan organik sebagai pupuk. Pada pertanian organik, salah satu pupuk organic yang digunakan adalah pupuk kompos bokashi. Penambahan kompos bokashi ke dalam tanah dapat meningkatkan kandungan bahan organik di dalam tanah dan mendorong pembiakan mikroorganisme tanah (Siregar, Dermiyati, dan Niswati, 2007).

Pupuk organik adalah pupuk yang tersusun dari materi organik atau makhluk hidup baik dari kotoran ternak maupun bagian dari tanaman. Pupuk organic dapat berbentuk padat atau cair, sebagian besar pupuk organic berbentuk padat seperti pupuk kandang dan kompos. Pupuk organic digunakan untuk mensuplai bahan organik, memperbaiki sifat fisik, kimia, dan biologi tanah. Produk yang dihasilkan dari budidaya yang menggunakan pupuk organik memiliki nilai jual yang lebih tinggi (Pranata, 2007).

Salah satu jenis pupuk organik yang sekarang banyak digunakan adalah pupuk bokashi. Bokashi adalah suatu kata dalam bahasa Jepang yang berarti "bahan organik yang telah difermentasikan". Pupuk Bokashi dibuat dengan memfermentasikan bahan-bahan organik (dedak, ampas kelapa, tepung 
ikan, dan sebagainya) dengan EM (Efektive Microorganism). Biasanya Bokashi ditemukan dalam bentuk serbuk atau butiran. Bokashi sudah digunakan para petani Jepang dalam perbaikan tanah secara tradisional untuk meningkatkan keragaman mikroba dalam tanah dan meningkatkan persediaan unsur hara bagi tanaman (Nasir, 2008).

Upaya yang dilakukan kepada kelompok adalah usaha pemanfaatan limbah ternak dan sampah atau sisa daun-daun yang digunakan dalam proses pembuatan pupuk bokhasi. Pupuk Bokashi kurang lebih dapat diartikan sebagai "Bahan Organik yang telah difermentasikan". Bokashi adalah hasil fermentasi atau peragian bahan-bahan organik seperti sekam, serbuk gergaji, jerami, kotoran hewan atau pupuk kandang, dan lain-lain bahan organik. Bahan-bahan tersebut difermentasi dengan bantuan microorganisme activator untuk mempercepat prosesnya. Bokhasi hasil produksi dimanfaatkan sebagai pupuk organik pada tanaman dengan cara ditaburi di atas bedengan sebagai media dan sumber nutrisi bagi tanaman. Pemberian pupuk bokhasi pada tanaman kedelai dapat meningkatkan pertumbuhan dan hasil tanaman yang tinggi (Asie, 2007)

Demplot yang dibuat pada pekarangan-lahan kering didukung oleh adanya irigasi semprot bawah mulsa (ProBaSa) yang dikembangkan oleh dosen Politani Negeri Kupang yang sangat menolong dalam pengunaan efisiensi air, mengingat demplot yang ada menggunakan air tangki yang dibeli. Teknologi irigasi ProBasa juga sangat membantu petani dalam memudahkan penyiraman pada tanaman, sehingga waktu dan tenaga petani lebih banyak dicurahkan dalam perawatan tanaman.

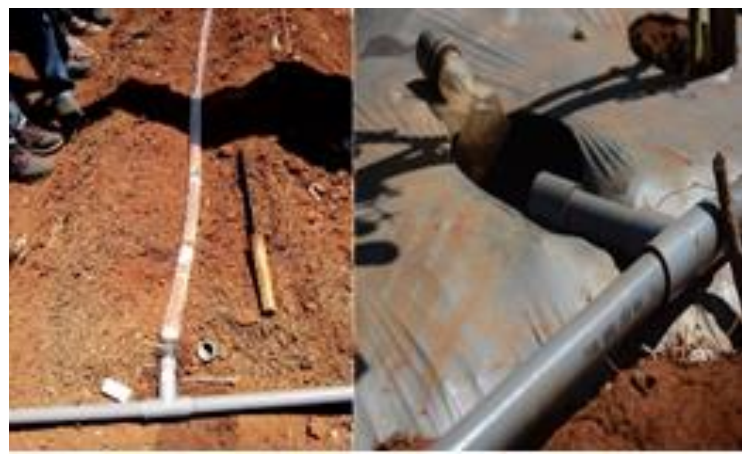

Gambar 1. Irigasi Semprot Bawah Mulsa (ProBaSa)

Pembuatan demplot ini diharapkan akan menjadi stimulan nyata bagi masyarakat sekitar untuk dapat juga memanfaatkan limbah rumah tangga pada tanaman hortikultura bahkan dapat membantu petani yang terlibat dalam menambah pendapatanya. Dalam pelaksanaan pembuatan demplot, tim pengabdian bekerjasama dengan PT. West-East Seed - Cap Panah Merah (Panah Merah) dalam penyediaan bibit unggul hortikultura dan juga pendampingan bagi petani mitra. Bahkan dengan menggandeng Bank NTT, tim pengabdian bersama Panah Merah juga melakukan Farmer's Field Day yang telah dilaksanakan pada Selasa, 16 Agustus 2016 di lokasi demplot. Pada kesempatan ini, turut hadir perwakilan seluruh kelompok tani (tujuh belas kelompok tani) yang ada di Desa Baumata, 
beberapa perwakilan kelompok tani dari desa lainnya se-kecamatan Taebenu, petani-petani pelopor dampingan Panah Merah, Camat Taebenu dan staf, serta para tenaga PPL. Bahkan banyak sekali kelompok tani lainnya, masyarakat sekitar maupun dari desa lain, jemaat gereja-gereja sekitar bahkan dinas pertanian kabupaten Sabu Raijua juga melakukan studi banding di lokasi demplot.

Adapun beberapa komoditi yang telah diusahakan dari awal pembuatan demplot hingga sekarang ini yaitu tomat, melon, sawi, kangkung, kacang panjang, buncis, cabe dan terung. Bahkan beberapa komoditi seperti sayuran, tomat dan melon sudah dan sementara melalui masa panen. Usaha pertanian lahan kering dengan pemanfaatan limbah bokhasi yang dilakukan oleh petani pada lokasi demplot dinilai berjalan dengan sangat baik. Bahkan demplot juga telah memberikan tambahan pendapatan yang cukup signifikan bagi petani. Jumlah tanaman tomat yang ditanam sebanyak 1000 pohon dengan produksi rata-rata per pohon sebesar $2,5 \mathrm{~kg} /$ pohon. Hasil produksi tanamana tomat kelompok tani Tunas Baru sebesar $25.000 \mathrm{~kg}$ atau 2,5 ton. Penjualan tomat dengan harga sebesar Rp. 10.000/kg maka penerimaan yang diperoleh adalah Rp. 25.000.000. Hal ini sesuai dengan Purtikoningrum (2009) menyatakan bahwa biaya yang dikeluarkan dalam usaha tani padi variatas IR 64 dengan menggunakan pupuk bokhasi lebih rendah dibandingkan dengan usaha dengan menggunakan pupuk anorganik ( \pm Rp. 6.582.428,51 /Ha/MT : Rp. 6.673.425,96/Ha/MT)

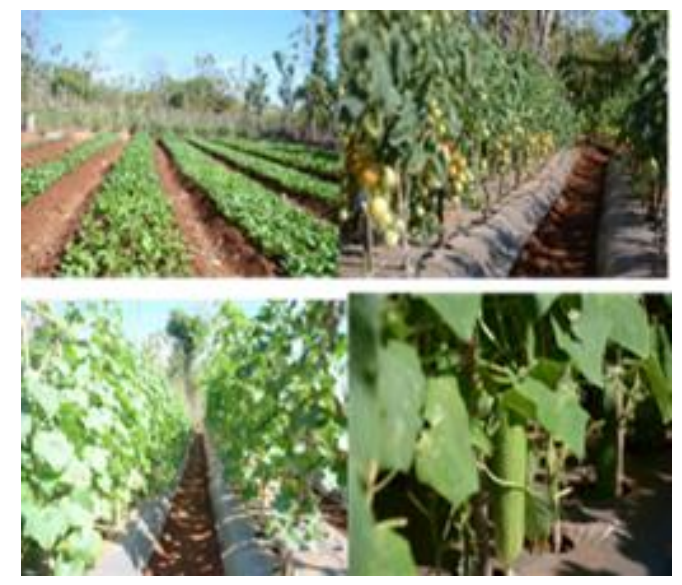

Gambar 2. Hasil Produksi Hortikulturan (Sayur Putih, Tomat, Melon, Timun, Paria)

\section{Hidroponik dan Polibag}

Pembuatan hidroponik dan penanaman sayuran dalam polybag di kelompok kaum Bapak Jemaat Bait El Kampung Baru Penfui dengan memanfaatkan pekarangan rumah. Hidroponik adalah budidaya menanam dengan memanfaatkan air tanpa menggunakan tanah dengan menekankan pada pemenuhan kebutuhan nutrisi bagi tanaman. Kebutuhan air pada hidroponik lebih sedikit dari pada kebutuhan air pada budidaya dengan tanah. Teknik cara menanam hidroponik menggunakan media air 
ini ditujukan untuk para pemula yang baru saja mengenal tanaman hidroponik dan ingin mencoba menanam sayuran hidroponik seperti, kangkung, bayam, seledri dan lain-lain. Penanaman dengan teknik hidroponik, tidak membutuhkan peralatan ataupun bahan-bahan yang sulit diperoleh tapi dapat memanfaatkan bahan yang sudah ada di sekitar anda seperti botol bekas, botol gantung dan media tanam sederhana lainnya.

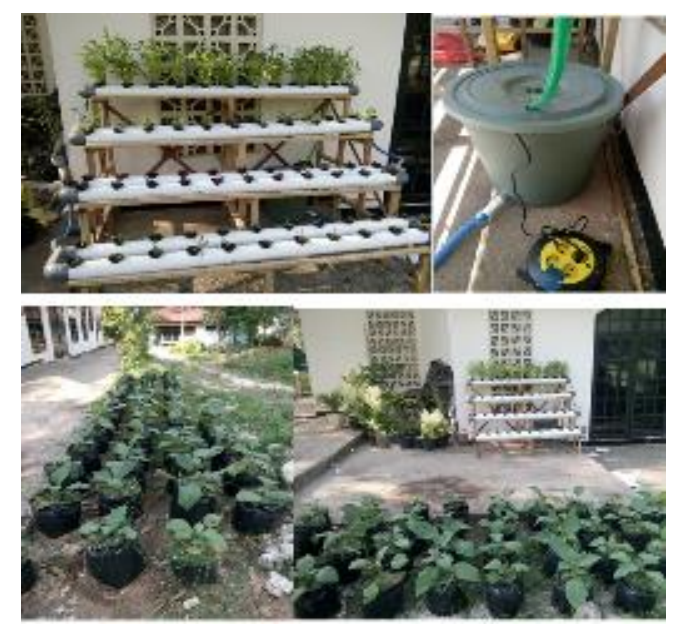

Selama ini untuk memenuhi kebutuhan rumah tangga, kita sering memanfaatkan lahan sempit di pekarangan untuk ditanami sayuran. Lahan pekarangan yang sempit membuat kita sering mengalami kesulitan mendapatkan tempat untuk bertanam. Media tanam merupakan salah satu faktor penting yang sangat menentukan dalam kegiatan bercocok tanam. Media tanam akan menentukan baik buruknya pertumbuhan tanaman yang pada akhirnya mempengaruhi hasil produksi. Menanam sayuran dalam pot / polybag merupakan salah satu alternative yang perlu dilakukan untuk memenuhi kebutuhan sendir atau untuk usaha komersial. Untuk itu dapat dipakai polybag (plastik hitam) dengan pertimbangan tidak usah membeli pot yang lebih mahal harganya. Dengan sempitnya lahan yang bisa ditanami, banyak orang yang mulai menanam sayuran dalam polybag. Selama ini, sayuran yang ditanam dalam pot terbatas pada cabe atau tomat saja. Tanaman dalam pot cukup mudah perawatannya karena bisa dipindah-pindah, ditaruh di tempat yang kita kehendaki, atau kalau perlu diganti potnya dengan yang lebih besar. Tanah yang sudah berkurang kesuburannya bisa diganti dengan tanah kebun yang lebih subur. Yang dimaksud dengan pemeliharaan tanaman bukanlah sekedar merawat tanaman yang sedang terserang penyakit saja, tetapi meliputi pemeliharaan secara lengkap, mulai dari menaruh polybag, menyirami tanaman, menyiang rumput, menggemburkan tanah, memupuk, memberantas hama dan penyakit, sampai dengan membongkar tanah polybag lama dan menggantinya dengan yang baru. Dengan memakai polybag kita tidak perlu lagi mengolah tanah yang akan ditanami. Cukup mencampur tanah dengan bokhasi atau pupuk kandang dan pasir dengan perbandingan 1:1:1 dan diisikan ke dalam polybag. Kemudian Polybag diatur agar nantinya bisa berdiri tegak. Polybag diisi 
dengan tanah sampai kira-kira $5 \mathrm{~cm}$ di bawah permukaan polybag. Dibanding dengan pot, penggunaan polybag jauh lebih murah. Sayuran yang ditanam dalam polybag lebih mudah dipindahkan ke tempat yang dikehendaki.

\section{SIMPULAN}

1. Tersedianya Kebun contoh tanaman hortikultura semi organik di lahan kering

2. Peningkatan pengetahuan tentang pemanfaatan lahan kering dengan menggunakan bokhasi, irigasi Probasa, hidroponik dalam meningkatkan produksi tanaman hortikultura.

3. Peningkatan pendapatan petani dalam usaha tanaman hortikulrura pada lahan kering

\section{DAFTAR PUSTAKA}

Asie, E. R. 2007. Karakteristik Tumbuh dan Hasil Empat Variatas Kedelai pada berbagai dosis bokhasi pada tanaman gambut pedalaman. Agrista Vol. 11 No. 3. Hal: 145-150.

Purtikoningrum, W. 2009. Penggunaan Pupuk organic Bokhasi Ditinjua dari peningkatan pendapatan petani pada usahatani pada variatas ir 64 di kabupaten karanganyar. Skripsi Fakultas Pertanian Universitas sebelas maret Surakarta.

Nasir. 2008. Pengaruh Penggunaan Pupuk Bokashi Pada Pertumbuhan Dan Produksi Padi Palawija Dan Sayuran. http://www.dispertanak.pandeglang.go.id/. Diakses tanggal 20 Nopember 2016.

Siregar, I. H., Dermiyati dan A. Niswati. 2007. Perubahan Populasi Mikroor-oganisme Tanah Akibat Pemberian Bokashi Berkelanjutan pada Sistem Pertanian Organik di Kecamatan Pagelaran Kabupaten Tanggamus. http://www.unila.ac.id/fp. Diakses pada tanggal 20 Desember 2016.

Pranata, A. S. Pupuk Organik Cair. Agromedia Pustaka. Jakarta. 